\title{
KAJIAN PENGGUNAAN COPPER SLAG SEBAGAI AGREGAT HALUS BETON
}

\author{
The Study Of Cooper Slag as Fine Aggregate Concrate \\ Rofikatul Karimah \\ Jurusan Teknik Sipil Fakultas Teknik Universitas Muhammadiyah Malang \\ Jln Raya Tlogomas 246 Malang 65144 \\ Email : rofikatulkarimah@gmail.com
}

\begin{abstract}
The use of copper slag as a partial replacement for copper slag fine aggregate shape and gradation that mimic natural sand. Physical form of copper slag are shaped flat and pointy (sharp) and most of the iron oxides and silicates, and have stable chemical properties. The chemical composition of copper slag composed of $\mathrm{Fe} 2 \mathrm{O} 3$, SiO2, $\mathrm{CaO}$, Al2O3. This research was conducted to determine the effect of the use of copper slag as a partial replacement of fine aggregate to the weight of the contents, the compressive strength and split tensile strength of concrete with the use of copper slag variation of 0\%, 20\%, 40\%,60\%,80\% and 100\% of the volume of fine aggregate. The results showed that the use of copper slag increase the weight of the contents, the compressive strength and split tensile strength of concrete. From the test results, increasing the variation in the provision of copper slag also increases the weight of the concrete. The highest compressive strength variation of $60 \%$ at $35.73 \mathrm{MPa}$, an increase of $22.32 \%$. And for the highest split tensile strength occurred in $60 \%$ of variation of $3.12 \mathrm{MPa}$, an increase of $5.76 \%$.
\end{abstract}

Keywords: Copper Slag, Concrete

\section{Abstrak}

Penggunaan copper slag sebagai bahan pengganti sebagian agregat halus karena copper slag memiliki bentuk dan gradasi yang menyerupai pasir alam. Bentuk fisik copper slag yaitu berbentuk pipih dan runcing (tajam) dan sebagian besar mengandung oksida besi dan silikat serta mempunyai sifat kimia yang stabil. Komposisi kimia copper slag terdiri dari $\mathrm{Fe}_{2} \mathrm{O}_{3}, \mathrm{SiO} 2$, $\mathrm{CaO}, \mathrm{Al}_{2} \mathrm{O}_{3}$. Penelitian ini dilakukan untuk mengetahui pengaruh penggunaan copper slag sebagai pengganti sebagian agregat halus terhadap berat isi, kuat tekan, dan kuat tarik belah beton dengan variasi penggunaan copper slag sebesar 0\%, 20\%, 40\%, 60\%, 80\% dan 100\% dari volume agregat halus. Hasil penelitian menunjukan bahwa penggunaan copper slag dapat meningkatkan berat isi, kuat tekan dan kuat tarik belah beton. Dari hasil pengujian, semakin bertambah variasi pemberian copper slag maka semakin bertambah pula berat isi beton tersebut. Kuat tekan tertinggi terjadi pada variasi $60 \%$ sebesar $35,73 \mathrm{MPa}$ atau naik sekitar $22,32 \%$. Dan untuk kuat tarik belah tertinggi terjadi pada variasi $60 \%$ sebesar $3,12 \mathrm{MPa}$ atau naik sekitar $5,76 \%$.

Kata kunci : Copper Slag, Beton

\section{PENDAHULUAN}

\begin{abstract}
Beton merupakan salah satu material konstruksi yang terus mengalami perkembangan, baik dalam hal bahan-bahan pembentuk betonnya maupun dalam hal metode pelaksanaannya. Seiring dengan semakin banyaknya pemakaian beton di dalam industri konstruksi maka semakin banyak dilakukan perubahan atau penggantian material campuran beton atau modifikasi beton yang diharapkan dapat meningkatkan mutu beton dan mereduksi permasalahan lingkungan.
\end{abstract}

Dari permasalahan inilah banyak alternatif yang dilakukan dalam penggantian material penyusun beton. Salah satunya adalah dengan mengganti sebagian agregat halus (pasir alam) yang biasa digunakan sebagai bahan pengisi pada beton dengan mengunakan salah satu limbah industri yang berpotensi sebagai pengganti sebagian agregat halus. Inovasi ini diharapkan berguna dan bernilai ekonomis tinggi. Salah satu limbah industi yang digunakan sebagai alternative pengganti agregat halus adalah terak tembaga (copper slag).

Copper slag adalah hasil limbah industri peleburan tembaga, berbentuk pipih 
dan runcing (tajam) dan sebagian besar mengandung oksida besi dan silikat serta mempunyai susunan kimia Silicon Dioxide (SiO2) sekitar $30-36 \%$, Iron Oxide $(\mathrm{FeO})$ mencapai $45-55 \%$, Calcium Oxide $(\mathrm{CaO})$ sekitar $2-7 \%$, Alumunium Oxide (Al2O3) sekitar 3 - 6\%.(PT. Smelting, Gresik, Jawa Timur). Pertimbangan pemakaian copper slag dalam penelitian ini dikarenakan copper slag dalam campuran beton di duga mempuyai beberapa keuntungan antara lain meningkatkan kekuatan beton,meningkatkan ketahanan terhadap sulfat dalam air laut,mengurangi panas hidrasi, menurunkan suhu dan memperkecil porositas, mengurangi serangan alkali-silika dan klorida. Disamping itu copper slug merupakan limbah yang dihasilkan oleh PT. Smelting Company Gresik dalam jumlah sangat banyak \pm 200.000 ton/th.

Tujuan dari penelitian ini adalah untuk mengetahui pengaruh penggunaan copper slag sebagai pengganti sebagian agregat halus terhadap berat isi beton, kuat tekan dan kuat tarik belah beton. Serta untuk mengetahui persentase optimum penggunaan copper slag sebagai pengganti sebagian agregat halus (pasir alam).

Bebarapa peneliti telah melakukan penelitian sejenis dan terus dikembangkan antara lain Kartini Wahyu (2009), melakukan penelitian tentang pengaruh penambahan copper slag sebagai pengganti sebagian semen pada beton mutu tinggi dengan FAS 0,35 . Dari hasil penelitian menunjukan bahwa ada peningkatan kuat tekan sebesar $10,48 \%$ pada variasi $20 \%$ copper slag.

Denny Ervianto (2010) meneliti tentang pembuatan beton dengan mutu super tinggi yang menggunakan konsep High Strength Self Compacting Concrete (HSSCC) dengan FAS 0,2 dan diberi tambahan superplasticizer, copper slag dan silica fume. Dan dalam penelitian ini diberikan penambahan copper slag bubuk dan silica fume pada HS-SCC karena kedua material tersebut memiliki kadar $\mathrm{SiO}_{2}$ yang dapat menambah kuat tekan beton. Tes tekan akan dilakukan pada umur 1,3,7,dan 14 hari. Dan hasil dari penelitian ini didapat bahwa dengan menambahkan bahan tambah copper slag dan silica fume dapat memberi dampak yang positif yaitu terjadi peningkatan kuat tekan beton HS-SCC pada umur 14 hari yaitu sebesar $60 \mathrm{Mpa}$.

\section{Berat Isi Beton}

Berat isi beton adalah rasio antara berat beton dengan volume beton. Untuk mengetahui berat isi beton digunakan rumus sebagai berikut :

$$
\begin{aligned}
& \text { Nilai Berat Isi }=\frac{\mathrm{b}}{\mathrm{v}} \\
& \text { Keterangan : } \quad \mathrm{b}=\text { Berat beton } \\
& \mathrm{v}=\text { Volume beton }
\end{aligned}
$$

\section{Kuat Tekan Beton}

Kuat tekan adalah kemampuan beton untuk menerima gaya tekan per satuan luas. Kekuatan beton akan bertambah dengan naiknya umur beton. Biasanya kekuatan tekan rencana beton dihitung pada umur 28 hari. Dengan rumus (SNI 03-1974-1990) :

$$
\text { Kuat tekan beton }=\frac{\mathrm{P}}{\mathrm{A}} \quad\left(\mathrm{kg} / \mathrm{cm}^{2}\right)
$$

Ket: $\mathrm{P}=$ Beban maksimum $(\mathrm{kg})$

$A=$ Luas penampang benda uji $\left(\mathrm{cm}^{2}\right)$

\section{Kuat Tarik Belah Beton}

Kuat tarik beton berpengaruh dalam kemampuan beton di dalam mengatasi retak awal sebelum dibebani. Kuat tarik belah beton dapat dihitung berdasarkan SNI 032491-1991 sebagaimana terlihat dalam rumus dibawah ini.

$$
\text { Kuat Tarik Belah (ft') }=\frac{2 \cdot \mathrm{P}}{\pi \cdot \mathrm{D} \cdot \mathrm{L}}
$$

Ket : $\quad \mathrm{P}=$ Beban yang terjadi $(\mathrm{kg})$

$\mathrm{D}=$ Diameter benda uji $(\mathrm{cm})$

$\mathrm{L}=$ Panjang benda uji $(\mathrm{cm})$

\section{METODE PENELITIAN Lokasi Penelitian}

Pelaksanaan penelitian ini dilakukan di Laboratorium Beton Teknik Sipil Universitas Muhammadiah Malang yang dimulai dari pemeriksaan material, pembuatan benda uji, perawatan benda uji, dan pengujian benda uji. 


\section{Rancangan Penelitian}

Penelitian ini dilakukan tiga tahap. Tahap pertama adalah tahap persiapan diawali dengan pengadaan semen, pasir, air dan copper slag. Kemudian dilanjutkan dengan pemeriksaan material meliput semen, pasir,kerikil dan copper slag. Karena sifat fisik copper slag yang hampir menyerupai pasir (agregat halus) maka untuk pemeriksaan materialnya diperlakukan sama seperti pemeriksaan material agregat halus meliputi: Pemeriksaan susunan gradasi, pemeriksaan berat jenis dan pemeriksaan penyerapan (absorsi). Tahap kedua adalah tahap pelaksanaan penelitian dengan penyusunan mix design, pengecoran dan pembuatan benda uji silinder beton. Jumlah benda uji yang digunakan dalam penelitian ini sebanyak 60 buah dengan ukuran $15 \times 30$ $\mathrm{cm}$ dengan masing-masing variasi prosentase copper slag sebesar $0 \%, 20 \%, 40 \%, 60 \%$, $80 \%$ dan $100 \%$ dari volume pasir. Tahap ketiga adalah tahap pengujian berat isi beton, kuat tekan (SNI 03-1974-1990) dan kuat tarik belah beton (SNI 03-2847-1992). Properti benda uji tercantum pada tabel 1 dan gambar 1 berikut ini :

Tabel 1. Properti Benda Uji

\begin{tabular}{cccc}
\hline $\begin{array}{c}\text { Variasi } \\
\text { cacahan }\end{array}$ & $\begin{array}{c}\text { Bentuk } \\
\text { benda uji }\end{array}$ & $\begin{array}{c}\text { Kuat } \\
\text { Tekan }\end{array}$ & $\begin{array}{c}\text { Kuat } \\
\text { Tarik } \\
\text { Belah }\end{array}$ \\
\hline $0 \%$ & Silinder & 5 & 5 \\
$20 \%$ & Silinder & 5 & 5 \\
$40 \%$ & Silinder & 5 & 5 \\
$60 \%$ & Silinder & 5 & 5 \\
$80 \%$ & Silinder & 5 & 5 \\
$100 \%$ & Silinder & 5 & 5 \\
\hline \multicolumn{3}{c}{ Jumlah total benda uji } & 60 \\
\hline
\end{tabular}

HASIL DAN PEMBAHASAN Hasil Pengujian Material Penyusun Beton

- Semen

Tabel 2. Hasil Pengujian Semen

\begin{tabular}{llll}
\hline \multicolumn{1}{c}{ Jenis Pemeriksaan } & \multicolumn{1}{c}{ Standart } & \multicolumn{1}{c}{ Hasil Pengujian } & \multicolumn{1}{c}{ Syarat } \\
\hline berat jenis & ASTM C-188-44 & $3,155 \mathrm{gr} / \mathrm{cm}^{2}$ & $3,15-3,17 \mathrm{gr} / \mathrm{cm}^{2}$ \\
kehalusan & ASTM C-134-66 & $3,86 \%$ & $10 \%$ di atas saringan 200 \\
konsistensi & ASTM C-187-71 & $26,5 \%$ & - \\
Waktu ikat awal & ASTM C-191-71 & 120 menit & Lebih dari 60 menit \\
Waktu ikat akhir & ASTM C-191-71 & 175 menit & Kurang dari 8 jam \\
\hline \multicolumn{2}{c}{ Sumber :Hasil Penelitian } & &
\end{tabular}

Sumber : Hasil Penelitian

\section{- $\quad$ Agregat Halus (Pasir Alam)}

Tabel 3. Hasil Pengujian Pasir Alam

\begin{tabular}{llll}
\hline \multicolumn{1}{c}{ Jenis Pemeriksaan } & \multicolumn{1}{c}{ Standart } & \multicolumn{1}{c}{ Hasil Pengujian } & \multicolumn{1}{c}{ Syarat } \\
\hline Bahan lewat saringan no. 200 & ASTM C-117 & $4,4 \%$ & Kurang dari 5\% \\
Analisa saringan & ASTM C-136-46 & Daerah gradasi III & $2-3,5$ \\
Berat jenis & ASTM C-128-68 & FM =2,33 & $2,57 \mathrm{gr} / \mathrm{cm}^{2}$ \\
absorbsi & ASTM C-128-68 & $2,25 \%$ & $2,5-2,7 \mathrm{gr} / \mathrm{cm}^{3}$ \\
\hline
\end{tabular}

Sumber : Hasil Penelitian

\section{- Agregat Kasar}

Tabel 4. Hasil Pengujian Agregat Kasar

\begin{tabular}{|c|c|c|c|}
\hline Jenis Pemeriksaan & Standart & Hasil Pengujian & Syarat \\
\hline \multirow{2}{*}{ Analisa saringan } & \multirow{2}{*}{ ASTM C-136-46 } & (lampiran) & - \\
\hline & & $\mathrm{FM}=5,03$ & $5-8$ \\
\hline Berat jenis & ASTM C-128-68 & $2,605 \mathrm{gr} / \mathrm{cm}^{3}$ & $2,5-2,7 \mathrm{gr} / \mathrm{cm}^{3}$ \\
\hline Absorbsi & ASTM C-128-68 & $1,04 \%$ & kurang dari $3 \%$ \\
\hline Abrasi & ASTM C-131 & $18,75 \%$ & Maksimal $40 \%$ \\
\hline
\end{tabular}

Sumber : Hasil Penelitian 


\section{- Copper Slag}

Tabel 5. Hasil Pengujian Copper Slag

\begin{tabular}{ll}
\hline Karakteristik Copper Slag & \multicolumn{1}{c}{ Pembahasan } \\
\hline Bentuk & $\begin{array}{l}\text { Pipih, runcing } \\
\text { (tajam) }\end{array}$ \\
Berat Jenis & $3,18 \mathrm{gr} / \mathrm{cm}^{3}$ \\
Penyerapan & $0,91 \%$ \\
Analisa saringan & Daerah gradasi I \\
\hline Sumber $:$ Hasil Penelitian & FM $=3,34$ \\
\hline
\end{tabular}

Sumber : Hasil Penelitian

\section{Hasil Pengujian Benda Uji \\ - Berat Isi Beton}

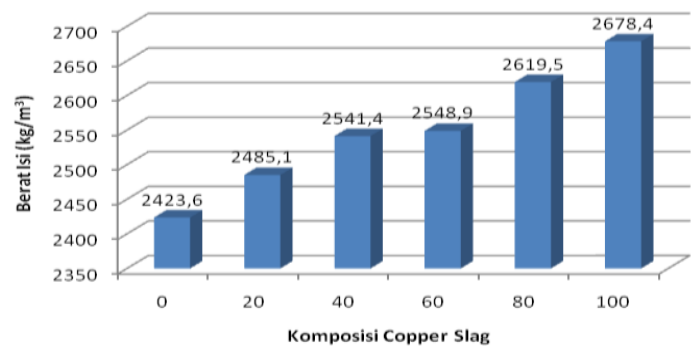

Gambar 1. Hubungan antara Komposisi Copper Slag dan Berat Isi

Dari hasil pengujian berat isi beton yang telah dilakukan terhadap benda uji menunjukkan adanya pengaruh penggunaan variasi copper slag sebagai pengganti sebagian agregat halus terhadap berat isi beton, pada pembacaan grafik dapat dilihat dengan semakin besarnya persentase agregat copper slag pada campuran beton maka berat isinya semakin bertambah.

\section{- Kuat Tekan Beton}

Dari hasil pengujian kuat tekan yang dilakukan disimpulkan semakin besar persentase agregat copper slag pada campuran beton maka kuat tekannya semakin bertambah. Kuat tekan tertinggi terjadi pada variasi $60 \%$ yaitu sebesar $35,73 \mathrm{MPa}$ atau mengalami peningkatan sebesar $22,32 \%$ dari beton normal. Hal ini dimungkinkan karena selain sifat filler juga sifat kimiawi copper slag yang mengandung $\mathrm{SiO} 2$ sehingga membantu kinerja semen sebagai bahan pengikat, sehingga dapat dihasilkan kuat tekan yang semakin tinggi seiring dengan meningkatnya persentase substitusi copper slag.

Sedangkan penggunaan copper slag .pada persentase $80 \%$ dan $100 \%$ justru menurunkan kuat tekan. Hal ini disebabkan karena penyebaran copper slag dalam adukan kurang merata, karena perbedaan berat jenis dan volume agregat yang besar, cenderung menyebabkan terjadinya segregasi (kecenderungan pemisahan bahan - bahan pembentuk beton).

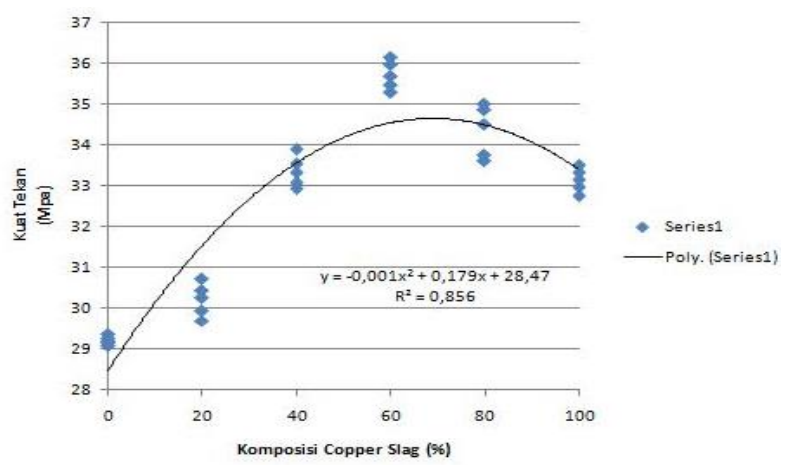

Gambar 2. Hubungan antara Komposisi Copper Slag dan Kuat Tekan Beton

- Kuat Tarik Belah Beton

Hasil pengujian kuat tarik belah beton dapat dilihat pada gambar berikut ini.

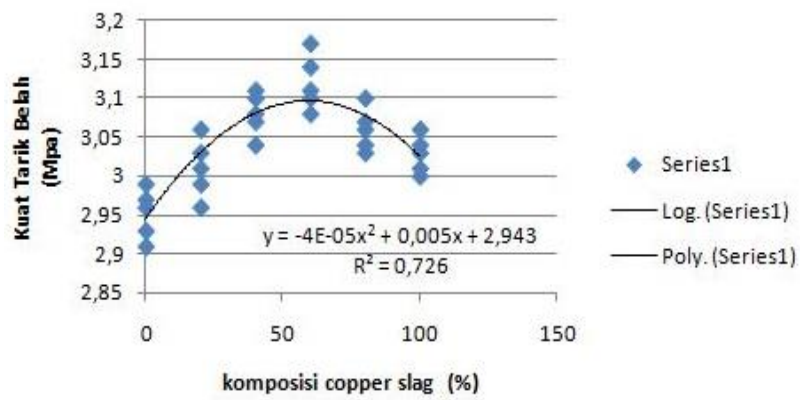

Gambar 3. Hubungan Copper Slag dan Kuat Tarik Belah

Dari hasil pengujian kuat tarik belah beton menunjukkan adanya pengaruh penggunaan variasi copper slag sebagai pengganti sebagian agregat halus terhadap kuat tarik belah beton. Kuat tarik belah tertinggi terjadi pada variasi $60 \%$ yaitu sebesar 3,12 $\mathrm{MPa}$ atau mengalami peningkatan sebesat 5,76\% dari kuat tarik belah beton normal. Sedangkan dari hasil perhitungan dengan menggunakan analisa regresi diperoleh nilai kuat tarik belah maksimum sebesar 3,23 MPa pada variasi komposisi copper slag sebesar 62,5\%. Sama halnya seperti pengujian kuat tekan beton 
penggunaan copper slag dapat meningkatkan kuat tarik belah hal itu dapat terjadi karena dipengaruhi oeh bentuk dan tekstur permukaan agregat, bentuk copper slag yang runcing mempunyai kemampuan untuk saling mengunci, dan permukaan yang kasar mempunyai koefisien gesek yang tinggi sehingga mampu mengisi pori-pori diantara butiran-butiran gradasi pasir normal sehingga dapat meningkatkan kepadatan beton yang tentunya dapat meningkatkan kuat tarik belahnya.

\section{KESIMPULAN}

- Penggunakan copper slag sebagai pengganti sebagian agregat halusnya pada beton meningkatkan berat isi beton. Semakin bertambah variasi pemberian copper slag maka semakin bertambah pula berat isi beton tersebut.

- Penambahan copper slag $60 \%$ sebagai pengganti sebagian agregat halus dapat meningkatkan kuat tekan beton sebesar $22 \%$ dari beton tanpa penambahan copper slag.

- Penambahan copper slag $60 \%$ sebagai pengganti sebagian agregat halus juga dapat meningkatkan kuat tarik belah beton sebesar 5,76\% dari beton tanpa penambahan copper slag.

\section{DAFTAR PUSTAKA}

ASTM Standart, Destignation C 78 - 94, Standart Practice for Making and Curing Concrete Test Specimen in Laborator.

Denny Ervianto , 2010, High Strength Self Compacting Concrete. Tugas Akhir, Jurusan Teknik Sipil , Institut Teknologi Sepuluh November.

Departemen Pekerjaan Umum, Peraturan SNI (SNI 03-1974-1990), Metode Pengujian Kuat Tekan Beton.

Departemen Pekerjaan Umum, Peraturan SNI (SNI 03-2491-1991), Metode Pengujian Kuat Tarik Belah Beton.

Departemen Pekerjaan Umum, Peraturan SNI (SNI 03-6433-2000), Metode Pengujian Absorbsi Beton.

Mulyono T, 2003, Teknologi Beton, Penerbit Universitas Negeri Jakarta, Jakarta.

Tjokrodimulyo Kardiyono, 1992, Teknologi Beton, Alfiri, Yogyakarta.
Triono Budi Astanto, 2001, Konstruksi Beton Bertulang, Kanisius, Yogyakarta.

Samekto Wuryati dan Rahmadiyanto Candra, 2001, Teknologi Beton, Kanisius, Yogyakarta.

Wahyu Kartini, 2009, Pengaruh Copper Slag Sebagai Cementitious Terhadap Kuat Tekan Beton, Tugas Akhir Sarjana FTSP-UPN "Veteran" Jawa Timur. 